\title{
Pengaruh Promosi Terhadap Peningkatan Penjualan Pada PT. Daya Adicipta Wisesa
}

\author{
Jill Klara Hariman \\ Wilfried S. Manoppo \\ Dantje Keles

\begin{abstract}
Jurusan Ilmu Administrasi, Program Studi Administrasi Bisnis, Fakultas Ilmu Sosial dan Politik, Universitas Sam Ratulangi jillklara@gmail.com
\end{abstract}

\begin{abstract}
ABSTRAK
This study aims to measure the level of significance of the effect of promotion on increasing sales along with the magnitude of its influence. This research is quantitative descriptive by interpreting the results of simple correlation and regression analysis to see the relationship between the measured variables. While the sample used was 50 people, taken from 15 employees and 35 selected customers. From the data analysis found the significance value between the two variables $X$ to $Y$ is equal to $0,000<0,05$, it can be seen that the effect of promotion on increasing sales at PT. Daya Adicipta Wisesa is very significant. And for the amount of influence from variable $X$ to $Y$, it can also be seen from the constant value that is equal to 6.332. This means that if the influence of variable $X$ does not change, then the value of sales is only $63.32 \%$. Meanwhile, the coefficient value is 0.730 , which means that if the promotion conditions increase by 1 , then the effect on the increase in sales will also increase by $73 \%$. From these results, the decision making on the hypothesis, namely $H_{0}$ is rejected and accepts $H_{a}$ which states that promotion has a significant influence on increasing sales at PT. Daya Adicipta Wisesa.
\end{abstract}

Keyword : Promotion, Increased Sales, Marketing Strategy

\section{Pendahuluan}

Adanya perubahan yang begitu cepat dalam selera, teknologi dan persaingan usaha yang ketat merupakan suatu kenyataan yang dapat kita lihat, sehingga banyak perusahaan yang bersaing memperebutkan peluang pasar baik itu perusahaan yang menghasilkan produk sejenis maupun perusahaan yang menghasilkan produk beragam perusahaanperusahaan yang bergerak dalam bisnis otomotif tumbuh dengan pesat, sehingga menyebabkan persaingan yang semakin ketat rantai perusahaan.

Persiapan penerapan berbagai strategi penjualan dijadikan sebagai kesempatan untuk melakukan terobosan dalam perdagangan di era globalisasi dengan suatu keyakinan bahwa di era perdagangan bebas yang tidak di proteksi sama sekali. Hal tersebut, menjadi tumpuan perusahaan untuk tetap mampu bertahan adalah dengan mengembangkan berbagai inovasi yang kreatif sesuai selera pelanggan tapi juga 
yang tidak kalah pentingnya adalah kreativitas para karyawan dalam mengembangkan berbagai metode atau cara untuk melakukan promosi yang mampu meyakinkan pembeli yang pada akhirnya akan berdampak pada peningkatan penjualan suatu produk.

Mengamati kegiatan pada PT. Daya Adicipta Wisesa maka adanya promosi yang tepat diharapkan akan dapat terjalin komunikasi antara produsen, pihak penjual atau dealer dengan konsumen/saat ini banyak sekali agen dealer yang menjual kendaraan baik roda empat maupun roda dua yang beroperasi di pasaran, namun berdasarkan pengamatan peneliti di PT. Daya Cipta Wisesa banyak mendapat kunjungan konsumen, ada yang langsung melakukan transaksi pembelian maupun mereka yang sekedar melihat jenis atau type model kendaraan yang mereka inginkan apalagi produk yang dijual oleh PT. Daya Adicipta Wisesa adalah merek kendaraan yang sudah terkenal mulai dari masyarakat kalangan bawah, menengah maupun kalangan atas.

Dari hasil pengamatan penulis pada PT. Daya Adicipta Wisesa ditemukan beberapa hal yang masih perlu ditingkatkan pemasarannya yaitu menyangkut penyesuaian dan koordinasi untuk bisa menjangkau seluruh konsumen yang ada. Promosi yang selama ini dijalankan oleh perusahaan belum memberikan kontribusi secara maksimal dalam meningkatkan penjualan sehingga perlu dilakukan inovasi atau terobosan - terobosan baru disertai kreativitas yang tinggi untuk mendapatkan cara yang tepat dalam mempengaruhi dan menarik minat para pembeli atau konsumen guna meningkatkan penjualan. Sehubungan dengan uraian pada latar belakang permasalahan diatas maka penulis tertarik memiliki jadwal penelitian ini sebagai berikut : peranan promosi terhadap peningkatan penjualan PT. Daya Adicipta Wisesa.

\section{Promosi}

Promosi merupakan salah satu faktor penentu keberhasilan program pemasaran. Bagaimanapun kualitas suatu produk apabila konsumen tidak tahu dan tidak yakin bahwa produk tersebut memiliki kualitas dan berguna bagi mereka maka konsumen pun tidak akan tertarik untuk membelinya. Dengan kata lain, promosi juga merupakan bentuk komunikasi pemasaran yang aktivitas pemasarannya berusaha menyebarkan informasi, mempengaruhi, membujuk maupun mengingatkan pasar sasaran atas perusahaan dan produknya agar bersedia menerima, membeli dan loyal pada produk yang ditawarkan perusahaan yang bersangkutan (Tjiptono, 2015). 
Pemasaran modern bukan hanya memerlukan pengembangan produk yang baik, harga menarik, serta terjangkau oleh konsumen sasaran saja. Akan tetapi juga harus mampu berkomunikasi dengan konsumen yang ada sekarang maupun potensial sehingga dapat berperan sebagai komunikator sekaligus promotor.

\section{Periklanan}

Periklanan merupakan sarana perusahaan untuk mempengaruhi konsumen dan sebagai alat persaingan dengan perusahaan lain dalam usaha mendapatkan perhatian dan kesan dari pasar sasaran periklanan menurut Kotler (2009), iklan adalah segala bentuk presentasi non pribadi dan promosi gagasan, barang atau jasa oleh sponsor tertentu yang harus dibayar.

Definisi periklanan menurut Djaslim Saladin (2006), periklanan adalah suatu bentuk penyajian yang sifatnya non personal dan promosi ide, barang atau jasayang dibayar oleh sponsor.

Periklanan juga menurut Hasan (2008), merupakan setiap bentuk penyajian non personal dan promosi ide, barangbarang dan jasa yang dibayar oleh sponsor yang telah diidentifikasi.

Dari definisi-definisi diatas dapat disimpulkan bahwa periklanan merupakan alat promosi tidak langsung dalam non personal baik lisan dan visual melalui media komunikasi massa yang intinya menarik perhatian para konsumen dengan tujuan meningkatkan penjualan barang dan jasa yang dibiayai oleh sponsor adapun penyajiaanya merupakan message sponsor.

\section{Penjualan}

Secara sederhana, penjualan adalah proses perpindahan hak milik akan suatu barang atau jasa dari tangan pemiliknya kepada calon pemilih baru (pembeli) dengan suatu harga tertentu, dan harga tersebut diukur dengan satuan uang. Tujuan penjualan oleh suatu perusahaan adalah untuk meningkatkan volume penjualan sehingga dapat diperoleh laba yang maksimal. Dengan keuntungan yang diperoleh maka suatu perusahaan dapat menjalankan operasional perusahaan sehingga perusahaan dapat berkembang sesuai yang diharapkan. Total penjualan yang diperoleh dalam suatu periode tertentu disebut volume penjualan. Penjualan merupakan pendapatan yang diterima dari pertukaran barang dan jasa yang dicatat dari suatu periode akuntansi tertentu, baik berdasarkan kas (sebagaimana diterima) atau berdasarkan aktual (sebagaimana diperoleh) Syahrul dan Nizar (2000).

Menurut Assauri (2004). kegiatan penjualan merupakan kegiatan pelengkap atau suplemen dari pembelian untuk 
memungkinkan terjadinya transaksi. Jadi kegiatan pembelian dan penjualan merupakan satu kesatuan untuk dapat terlaksananya transfer hak atau transaksi. Oleh karena itu, kegiatan penjualan terdiri dari serangkaian kegiatan yang meliputi penciptaan permintaan (demand), menemukan si pembeli, negosiasi harga dan syarat-syarat pembayaran.

\section{Faktor-faktor Yang Mempengaruhi Penjualan}

Menurut Basu Swastha (2005) sebagai berikut :

a. Kondisi dan kemampuan penjual

Disini penjual harus dapat meyakinkan kepada pembelinya agar dapat mencapai sasaran penjualan yang diharapkan. Untuk maksud tersebut para penjual harus memahami beberapa masalah penting yang sangat berkaitan yaitu :

- Jenis dan karakteristik barang atau jasa yang ditawarkan

- Harga produk atau jasa

- Syarat penjualan, seperti: pembayaran, pengiriman

b. Kondisi pasar

Kondisi pasar dipengaruhi oleh beberapa faktor yakni: jenis pasar, kelompok pembeli, daya beli, frekuensi pembelian serta keinginan dan kebutuhannya.

c. Modal
Dana awal atau modal perusahaan dalam penjelasan ini adalah modal kerja perusahaan yang digunakan untuk mencapai target penjualan yang dianggarkan, misalnya dalam menyelenggarakan stok produk dan dalam melaksanakan kegiatan penjualan memerlukan usaha seperti alat transportasi, tempat untuk menjual, usaha promosi dan sebagainya.

d. Kondisi organisasi perusahaan

Pada perusahaan besar biasanya masalah penjualan ditangani oleh bagian penjualan yang dipegang oleh orang-orang tertentu/ahli dibidang penjualan lain halnya dengan perusahaan kecil masalah-masalah penjualan ditangani oleh orang-orang yang juga melakukan fungsi lain. Hal ini disebabkan oleh tenaga kerjanya yang lebih sedikit. Sistem organisasi juga lebih sederhana masalah-masalah yang dihadapinya juga tidak kompleks.

\section{Hipotesis}

Hipotesis merupakan suatu jawaban yang bersifat sementara terhadap permasalahan penelitian sampai terbukti melalui data yang terkumpul (Suharsimi Arikunto, 1998) sehubungan dengan permasalahan penelitian ini dan bertitik tolak dari uraian - uraian tersebut diatas maka dapatlah ditarik suatu hipotesa penelitian sebagai berikut : "Ada Pengaruh 
Promosi Terhadap Peningkatan Penjualan

Pada PT. Daya Adicipta Wisesa"

\section{Metode Penelitian}

Sumber data yang digunakan dalam penelitian ini terdiri dari dua macam yaitu data primer dan data sekunder. Proses pengumpulan data yang diperlukan dalam penelitian ini melalui dua tahap yaitu :

\section{Studi Kepustakaan (library research)}

Studi kepustakaan digunakan untuk mengumpulkan data sekunder dari perusahaan yang berkaitan dengan penelitian ini. Hal ini dilakukan untuk mendapatkan tambahan pengetahuan mengenai topik yang sedang dibahas.

\section{Studi Lapangan (field research)}

Penelitian lapangan dilakukan dengan cara:
a. Wawancara
b. Observasi
c. Kuesioner

Untuk memilah data dari responden yang berupa daftar pertanyaan kualitatif, maka jawaban diberi skor atau ranking sehubungan dengan hal tersebut maka dalam penelitian ini digunakan skala likert yang menggunakan interval penilaian setiap jawaban responden dengan angka 1 - 5 .

Menurut Sugiono (2000) skala Likert digunakan untuk mengukur sikap, pendapat dan persepsi seseorang atau sekelompok orang tentang fenomena sosial dengan gradasi dan sangat positif sampai dengan sangat negatif.

Untuk mengkuantitatifkan data dari responden yang berupa daftar pertanyaan kualitatif, maka jawaban diberi skor atau ranking. Sebagai contoh alternatif jawaban yang diberikan untuk setiap item pernyataan kuesioner adalah:

\begin{tabular}{lc}
\hline \multicolumn{1}{c}{ Pernyataan } & Skor \\
\hline Sangat sesuai & 5 \\
Sesuai & 4 \\
Cukup Sesuai & 3 \\
Tidak Sesuai & 2 \\
Sangat Tidak Sesuai & 1 \\
\hline
\end{tabular}

Sumber: Sugiyono, 2000

Teknik Analisis Data

Koefisien korelasi digunakan untuk mengetahui hubungan variabel bebas (x) terhadap variabel terikat (y) dengan mengikuti formula Pearson :

$$
r=\frac{n \sum x y-\left(\sum x\right)\left(\sum y\right)}{\left.\sqrt{\left\{n\left(\sum x^{2}\right)\right.}-\left(\sum x\right)^{2}\right\}\left\{n\left(\sum x^{2}\right)-\left(\sum y\right)^{2}\right\}\left\{n\left(\sum y\right)^{2}\right\}}
$$

Keterangan :

$\mathrm{r} \quad$ : Koefisien korelasi

$\mathrm{n} \quad$ : Jumlah data

$\sum x$ : Jumlah variable $\mathrm{x}$ (peranan promosi)

$\sum y$ : Jumlah variable y (peningkatan penjualan)

Dan untuk menuji keberartian (hipotesis) digunakan uji signifikansi antara $\mathrm{x}$ dan $\mathrm{y}$ dengan menggunakan uji $\mathrm{t}$ dengan rumus sebagai berikut :

$t=\frac{r \sqrt{n-2}}{\sqrt{n-r^{2}}}$ 
Ket :

$\mathrm{t} \quad=\mathrm{t} u \mathrm{uj}$

$\mathrm{r} \quad=$ koefisien korelasi

\section{Hasil Penelitian}

\section{Deskripsi Hasil Penelitian}

Diketahui bahwa laki-laki berjumlah 7 orang (25\%), perempuan berjumlah 23 orang (75\%). Maka disimpulkan bahwa mayoritas responden di adalah perempuan.

Dari kelompok usia diketahui 25 - 30 tahun 8 orang $(25 \%)$, kelompok usia 31 40 tahun 12 orang (40\%), kelompok usia 41 - 50 tahun 4 orang $(12,5 \%)$ dan kelompok usia $51-70$ tahun 6 orang $(22,5 \%)$.

1. Pengaruh Promosi (X)

Distribusi Jawaban Responden Tentang Pengaruh Promosi

\begin{tabular}{clcc}
\hline No & $\begin{array}{c}\text { Pilih } \\
\text { Jawaban }\end{array}$ & Frekuensi & $\begin{array}{c}\text { Presentase } \\
(\%)\end{array}$ \\
\hline 1 & SS & 12 & 40 \\
2 & S & 6 & 20 \\
3 & CS & 7 & 23,3 \\
4 & TS & 3 & 10 \\
5 & STS & 2 & 6,7 \\
\hline & Jumlah & 30 & 100 \\
\hline
\end{tabular}

Sumber: Data Olahan, 2019

2. Peningkatan Penjualan (Y)

Distribusi Jawaban Responden Tentang Peningkatan Penjualan (Y)

\begin{tabular}{llcc}
\hline No & $\begin{array}{c}\text { Pilih } \\
\text { Jawaban }\end{array}$ & Frekuensi & $\begin{array}{c}\text { Presentase } \\
(\%)\end{array}$ \\
\hline 1 & SS & 14 & 46,67 \\
2 & S & 4 & 13,33 \\
3 & CS & 6 & 20,00 \\
4 & TS & 4 & 13,33 \\
5 & STS & 2 & 6,67 \\
\hline & Jumlah & 30 & 100 \\
\hline
\end{tabular}

Sumber: Data Olahan, 2019

\section{Uji Validitas}

Pengujian validitas menggunakan SPSS 25, dengan korelasi atau menghubungkan masing-masing skor dengan skor total yang diperoleh dalam penelitian. Nilai tabel dapat dilihat pada tabel $r$ statistik yang disebut dengan $\mathrm{N}=30$ pada level if signifikan $5 \%$ dan Nilai $\mathrm{r}$ tabel sebesar 0.3061 .

\section{Uji Reliabilitas}

\begin{tabular}{cccc}
\hline Variabel & $\begin{array}{c}\text { Cronbach's } \\
\text { Alpha }\end{array}$ & $\begin{array}{c}\text { r-tabel } \\
5 \%(30)\end{array}$ & Status \\
\hline $\begin{array}{c}\text { Pengaruh } \\
\text { Promosi } \\
(\mathrm{X})\end{array}$ & 0.805 & 0.3061 & Reliable \\
\hline $\begin{array}{c}\text { Peningkatan } \\
\text { Penjualan } \\
(Y)\end{array}$ & 0.765 & 0.3061 & Reliable \\
\hline
\end{tabular}

Sumber: Data Olahan, 2019

\section{Uji t (Uji Hipotesis)}

\begin{tabular}{ccccccc}
\hline & & \multicolumn{2}{c}{ Unstand } & \multicolumn{1}{c}{ Stand. } & & \\
Model & Coefficients & Coeff. & & \multirow{2}{*}{ Sig. } \\
\cline { 2 - 4 } & $\mathrm{B}$ & $\begin{array}{c}\text { Std. } \\
\text { Error }\end{array}$ & Beta & & \\
\hline & (Constant) & 6.332 & 2.310 & & 2.742 & .011 \\
1 & $\begin{array}{c}\text { Pengaruh } \\
\text { Promosi }\end{array}$ & .730 & .173 & .623 & 4.219 & .000 \\
\hline \multicolumn{7}{l}{ Dependent Variable: Volume Penjualan } \\
\end{tabular}

Dependent Variable: Volume Penjualan

Persamaan garis regresi linear sederhana untuk metode kuadrat terkecil (least squares method) yang didapat ialah : $\hat{\mathrm{Y}}=6,332+0,730 \mathrm{X}$. Persamaan regresi ini dapat dijelaskan sebagai berikut :

a. $\hat{Y}=$ Peningkatan Penjualan yang diduga; $\mathrm{X}=$ Pengaruh promosi;

b. Nilai konstanta a sebesar 6,332. Hal ini bermakma bahwa apabila peranan 
pengaruh promosi tidak berubah (konstan), maka besarnya nilai peningkatan pe jualan (Y) hanya sebesar 6,332.

c. Nilai koefisien $b=+0,730$, yang berarti apabila kondisi pengaruh promosi $(\mathrm{X})$ dinaikkan sebesar 1 skala per unit, maka pengaruhnya atas peningkatan penjualan akan naik sebesar $73 \%$.

\section{Koefisien Determinasi $\left(\mathbf{R}^{2}\right)$}

(Model Summary ${ }^{\mathrm{b}}$ )

\begin{tabular}{lllll}
\hline Model & $\mathrm{R}$ & R Square & $\begin{array}{c}\text { Adjusted } \\
\text { R Square }\end{array}$ & $\begin{array}{c}\text { Std. } \\
\text { Error } \\
\text { of t e } \\
\text { Estimate }\end{array}$ \\
\hline 1 & $.623^{\mathrm{a}}$ & .389 & .367 & 3.907 \\
\hline
\end{tabular}

Dependent Variable: Volume Penjualan

Hasil analisis data di atas menunjukkan bahwa nilai koefisien determinasi diperoleh sebesar 0,389. Hal ini menunjukkan bahwa peningkatan penjualan dipengaruhi oleh variasi dari variabel independen yang digunakan, yaitu pengaruh Promosi (X) sebesar 38,9 $\%$, sedangkan sisanya sebesar $61,1 \%$ dipengaruhi oleh faktor-faktor lain di luar model penelitian ini.

\section{Pembahasan}

PT. Daya Adicipta Wisesa melakukan strategi promosi dengan berbagai cara, diantaranya adalah sebagai berikut:
Periklanan Kegiatan periklanan dimaksudkan agar konsumen dapat mengenal produk yang dijual. Periklanan ini dilakukan dengan cara melakukan iklan melalui radio, surat kabar, dan televisi. PT. Daya Adicipta Wisesa memilih cara ini karena di era modern ini tentunya sebagian masyarakat sering mendengarkan radio, membaca surat kabar, terlebih lagi menonton televisi. Jadi cara ini sangat tepat digunakan untuk mempromosikan produk mereka. Selain itu, PT Daya Adicipta Wisesa menyebarkan brosur kepada masyarakat agar masyarakat dengan mudah dapat membaca dan mengenal produk Honda. Pada saat penyebaran brosur masyarakat dapat mengajukan pertanyaan secara langsung mengenai produk Honda kepada petugas yang 45 menyebarkan brosur. Tidak hanya melalui brosur akan tetapi dengan memasang poster spanduk, baliho, dan billboard di tempat yang strategis.

Promosi penjualan dilakukan dengan memberikan hadiah kepada konsumen pada setiap pembelian sepeda motor. Hadiah diberikan untuk menarik perhatian konsumen agar konsumen membeli produk yang dijual.

Personal Selling Kegiatan ini dilakukan dengan menggunakan sales, dimaksudkan agar calon pembeli dapat berkomunikasi langsung dengan petugas 
dan dengan jelas mendapatkan pengarahan dari petugas mengenai produk yang dijual.

Hasil analisis data menunjukkan bahwa hipotesis Promosi mempunyai pengaruh signifikan terhadap Peningkatan penjualan di PT. Daya Adicipta Wisesa", dapat diterima keberlakuaanya secara empiric dengan sangat meyakinkan.

Dengan terujinya hipotesis tersebut, maka hasil-hasil penelitian secara empirik dapat menjustifikasi teori-teori tentang pengaruh promosi terhadap peningkatan penjualan, khususnya penjualan di PT. Daya Adicipta Wisesa.

\section{Kesimpulan}

Hasil analisis data dengan menggunakan program SPSS for window versi 20, diperoleh hasil uji-t. Persamaan garis regresi linear sederhana untuk metode kuadrat terkecil (least squares method) yang didapat ialah $: \hat{\mathrm{Y}}=6,332+0,730 \mathrm{X}$. Deskripsi hasil uji-t sebagaimana menunjukkan bahwa harga t hitung sebesar 4,219 berada jauh diluar daerah penerimaan H0 (pihak kiri) bila dikonsultasikan dengan harga $\mathrm{t}$ tabel pada taraf uji $5 \%$ dengan $\mathrm{dk}=$ 28 diperoleh sebesar 2,021 $(-2,021<4,219$ $>$ 2,021). Hasil ini menunjukkan bahwa H0 ditolak dan menerima Ha yang menyatakan bahwa "Peranan Promosi mempunyai pengaruh signifikan terhadap Peningkatan Penjualan di PT. Daya Adicipta Wisesa”.
Hasil analisis data nilai koefisien determinasi diperoleh sebesar 0,389. Hal ini menunjukkan bahwa peningkatan penjualan dipengaruhi oleh variasi dari variabel independen yang digunakan, yaitu pengaruh Promosi (X) sebesar 38,9 \%, sedangkan sisanya sebesar 61,1 \% dipengaruhi oleh faktor-faktor lain di luar model penelitian ini.

Hasil analisis data menunjukkan bahwa hipotesis yang berbunyi "Peranan Promosi mempunyai pengaruh signifikan terhadap Peningkatan penjualan di PT. Daya Adicipta Wisesa", dapat diterima keberlakuaanya secara empiric dengan sangat meyakinkan.

\section{Saran}

Dari kesimpulan diatas, maka perlu disarankan sebagai berikut:

Pasar mempengaruhi kegiatan dalam transaksi penjualan baik sebagai kelompok pembeli atau penjual.

Disini penjual harus dapat meyakinkan kepada pembelinya agar dapat mencapai sasaran penjualan yang diharapkan, sehingga promosi meningkatan penjualan di PT. Daya Adicipta Wisesa", dapat diterima keberlakuaanya secara empirik dengan sangat meyakinkan.

Secara teoritis banyak alternative yang bisa ditempuh oleh perusahaan dalam rangka mencapai dan meningkatkan 
penjualan tanpa melupakan tujuan perusahaan yaitu volume perusahaan yang menguntungkan demi kelangsungan perusahaan.

Dan hal tersebut sangat menguntungkan pihak perusahaan sehingga walaupun banyak pesaing agar perusahaan tersebut tetap eksis dan setiap tahunnya mengalami peningkatan penjualan.

\section{Daftar Pustaka}

Tjiptono, F.2015. Strategi Pemasaran. Edisi Revisi. Penerbit CV. Andi OFFset. Yogyakarta.

Kotler, P.2009. Manajemen Pemasaran. Jakarat : Penerbit Erlangga

Saladin, D. 2006. Manajemen Pemasaran Edisi Keempat. Bandung : Penerbit Linda Karya

Hasan, A. 2008. Marketing.Yogyakarta : Penerbit Media Utama.

Swastha, B dan Irawan. 2005. Asas-asas Marketing. Yogyakarta : Penerbit " Liberty.

Sugiyono, 2000. Metode Penelition Kualitatif, Kuantitatif dan $R \& D$. Bandung : Penerbit Alfabeta 